\title{
AXILLARY LYMPH NODE DISSECTION COULD BE OMITTED IN THE BREAST CANCER PATIENTS WITH A LIMITED SENTINEL LYMPH NODE INVOLVEMENT FOLLOWING NEOADJUVANT SYSTEMIC TREATMENT
}

\author{
ANA CAR PETERKO ${ }^{1}$, MANUELA AVIROVIĆ ${ }^{2}$, PETRA VALKOVIĆ ZUJIĆ ${ }^{3}$ \\ KORALJKA RAJKOVIĆ MOLEK ${ }^{4}$, INGRID BELAC LOVASIĆ ${ }^{5}$ and FRANJO LOVASIĆ ${ }^{1}$ \\ ${ }^{1}$ Department of General Surgery and Surgical Oncology, Clinical Hospital Centre Rijeka, Rijeka Croatia; \\ ${ }^{2}$ Department of General Pathology and Pathologic Anatomy, University of Rijeka, Faculty of Medicine, \\ Rijeka, Croatia; \\ ${ }^{3}$ Department of Radiology, Clinical Hospital Centre Rijeka, Rijeka, Croatia; \\ ${ }^{4}$ Clinical Department of Pathology and Cytology, Clinical Hospital Centre Rijeka, Rijeka, Croatia; \\ ${ }^{5}$ Department of Radiotherapy and Oncology, Clinical Hospital Centre Rijeka, Rijeka, Croatia
}

\section{Summary}

Background: In modern breast cancer management, SLNB is a standard of care. For the patients with limited sentinel lymph node involvement in the upfront surgery setting, ALND can be safely omitted. However, for any sentinel node metastasis detected following neoadjuvant systemic treatment (NST), ALND is still considered a mandatory procedure.

Patients and methods: Present retrospective analysis has included all breast cancer patients submitted to surgery following NST in Clinical Hospital Centre (CHC) Rijeka in the period from 2017 till 2020.

Results: SLNB was performed in 151 of 222 consecutive patients, and sentinel node metastasis was detected in 49 cases. The risk of non-sentinel lymph node involvement in sentinel node-positive patients was $34.7 \%$, but exclusively for cases with macro-metastatic disease detected in the sentinel node. In addition, for the patients diagnosed with clinically uninvolved axilla, the risk of ypN2-3 status was only $2.8 \%$.

Conclusions: ALND following NST is overtreatment in $65.3 \%$ of sentinel node-positive patients. Axillary irradiation with the omission of ALND should be considered for the sentinel-positive patients with only micro-metastatic disease detected in the sentinel node following neoadjuvant chemotherapy, as well as for those with low volume macro-metastatic disease, diagnosed with the uninvolved axilla.

KEYWORDS: breast cancer, neoadjuvant chemotherapy, sentinel lymph node biopsy

\section{INTRODUCTION}

In modern breast cancer (BC) management, ALND is rarely performed procedure in the upfront surgery setting for the early-stage BC. SLNB

Corresponding author: Ana Car Peterko, Department of General Surgery and Surgical Oncology, Clinical Hospital Center Rijeka, Krešimirova 42, 51000 Rijeka, Croatia. e-mail: anacarpeterko@gmail.com is a standard of care for all patients presenting with clinically uninvolved axilla (cN0), although the false-negative rate (FNR) of axillary ultrasound (AUS) may be up to $30 \%$. Due to Z0011 and AMAROS trial results(1-3), ALND can be safely omitted even in those cases with up to 2 sentinel lymph nodes (SLN) involved with macro-metastatic disease, although in higher-risk cases axillary irradiation (AxRT) is recommended instead. 
In both mentioned trials, as well as in several other ALND-omission trials(1-6), the calculated risk of additional nodal involvement in the SLN-positive population is $13-38.5 \%$ and is correlated with the size of metastatic disease in SLN as well as with the number of involved SLN. However, after follow up period of 10 years, this risk of metastatic involvement of non-sentinel lymph nodes left behind, did not translate into any clinical significance in terms of higher rates of regional recurrences or poorer disease control and survival i.e., the omission of ALND did not alter the oncological outcomes in SLN positive populations of earlystage BC patients.

Nowadays, however, many early-stage BC patients commence treatment with neoadjuvant systemic treatment (NST). According to several validation trials(7-10) and all relevant BC management guidelines $(11,12)$, since 2017 SLNB is accepted as an option for axillary staging even after NST. However, the procedure is still not universally accepted as a standard of care. Moreover, ALND is still considered a mandatory procedure in all cases of metastatic disease detected in SLN, irrespective of its size and clinical nodal status $(\mathrm{cN})$ at presentation. This results in a paradoxical situation in a substantial number of cases diagnosed as $\mathrm{cN} 0$, but with the metastatic disease eventually detected in SLN following NST, especially those patients with micrometastatic or low volume macro-metastatic disease.

As the basis for this recommendation is a single randomized controlled study with a relatively low sample size(13) and is discordant with the clinical practice in our institution, we have undertaken the present analysis. The main purpose was to calculate the overall risk of additional nodal involvement and the risk of massive, clinically significant nodal involvement of non-sentinel lymph nodes, defined as ypN2-3 i.e., the only reasonable indication for therapeutic ALND, in the case of SLN positive disease following NST. In addition, we have searched for correlations of both calculated risks with the nodal status at presentation, size of SLN metastasis, and the number of involved SLN, as well as with other elements of the standard histopathological report.

\section{PATIENTS AND METHODS}

All BC patients in stage T1-3 N0-2 M0, submitted to surgery in Clinical Hospital Centre
(CHC) Rijeka following NST, in the period from 2017 till 2020, were included in the present analysis. Relevant data were extracted retrospectively from Integrated Hospital Informatics System (IBIS), analysed with Statistica 13.5 software, and interpreted at the level of statistical significance $\mathrm{p}=0.05$. Pearson Chi-square test, Fisher exact onetailed test and Mann-Whitney U test were used for testing the correlations between the elements of the histopathological report and calculated risk of non-sentinel lymph node involvement in SLN positive patients following NST.

The analysis was approved by the institutional ethics committee.

Before initiating NST, nodal status was determined by AUS (Logiq S8 and Logiq E9®), General Electric Healthcare, Chicago, USA) and dedicated breast MRI scanner (Magnetom Avanto and Aera ${ }^{\circledR}$, 1.5 T, Siemens, Erlangen, Germany) All suspicious appearing lymph nodes with cortical thickening > $3 \mathrm{~mm}$ were sampled under US guidance and the presence of metastasis was cytologically or histologically proven. Although most of those proven metastatic lymph nodes were marked with the tissue marker (titanium clip), confirmation of their removal following NST was not mandatory.

All patients received the standard neoadjuvant systemic protocol; 4 cycles of anthracyclines and cyclophosphamides followed with 12 cycles of taxanes, with the addition of dual anti-HER2 blockage for HER2 positive patients.

Before surgery nodal status was re-evaluated with the MRI and SLNB was performed for all patients with unsuspicious post-treatment axillary lymph nodes, irrespective of the initial nodal status.

The lymphoscintigraphy with technetium labelled nano-colloid particles was the most frequently used method for SLN detection, although other tracers (Magtrace ${ }^{\circledR}$ and methylene blue dye) were also used. Dual mapping was applied as a surgeon's choice i.e., it was not mandatory. The median number of removed SLN was 3, range from 1 to 8 . In 16 cases (11\% of patients submitted to SLNB), more than $5 \mathrm{LN}$ were removed during the procedure due to inadequate mapping or surgeons' choice to remove clinically suspicious lymph nodes in addition to true sentinel node(s).

All removed SLNs were intraoperative longitudinally transected on 3- $4 \mathrm{~mm}$ cuts and analyzed by imprint cytology. For all positive or suspected 
cases, cuts are frozen and histologically examined for presence or absence of metastasis. Sentinel lymph nodes negative on imprint cytology were transected sequentially in two to three levels for hematoxylin-eosin and pan-cytokeratin staining, therefore, detection of every residual tumor in the lymph node, including Isolated Tumor Cells (ITC), was ensured.

The pathologic stage of the primary tumor and lymph node was determined according to the 4th edition of WHO TNM classification form 2012(14) and the appendix of AJCC manual for breast cancer staging(15).

The standardized pathological report was used for primary tumor description, including histological type according to 4th edition of WHO TNM classification and appendix of AJCC manual for breast cancer staging, Nottingham combined histologic grade, tumor bed size, size of largest residual focus of tumor, percentage of cellularity, and percentage of ductal in situ carcinoma, number of positive lymph nodes and size of metastases. According to Detailed Pathology Methods for Using Residual Cancer Burden provided on MD Anderson Internet pages, pathologic residual cancer burden (pRCB) was calculated. Tumor infiltrating lymphocytes (TILs) were determined according to recommendations made by an International TILs Working Group 2014(16). Standard prognostic and predictive biomarkers as estrogen receptor (ER), progesterone receptor $(\mathrm{PR})$, and HER2 receptor were determined in every residual tumor and the immunophenotype was determined according to the ASCO CAP guidelines for ER and PR from 2020(17) and for HER-2 from 2018(18). Lymphatic vascular invasion (LVI) was, in most cases, confirmed with immunohistochemical staining of endothelial cells.

In addition to SLNB, ALND was performed in all SLN positive cases, regardless of the initial nodal status, size of the metastasis detected in SLN, the number of positive SLN, and time of detection (intraoperative and final pathological report).

The main purpose of the present analysis was to determine the risk of additional positive axillary lymph nodes among SLN positive patients, which we have defined and calculated as a rate of ALND positive patients in the SLN positive group.

Similarly, we have calculated the risk of the clinically significant (massive) nodal involvement, which we have defined as more than 2 non-SLNs harboring a metastatic disease in addition to involved SLN(s). Besides, we have determined and compared values of both above-mentioned risks in specific subgroups of SLN positive patients; cN0 and cN1-2, micro and macro-metastatic $\mathrm{SLN}(+)$ disease, and $\mathrm{SLN}(+)$ disease with up to 2 and more than 2 SLNs involved.

Finally, we have checked if there are any correlations among the risk of metastatic disease in non-SLN and standard elements of the histopathological report in SLN positive patients following NST i.e., if any of the current standard pathological biomarkers may help us in the decision-making process of omitting or proceeding with ALND in SLN positive patients following NST.

\section{RESULTS}

Overall, 222 consecutive, post-NST, BC patients were included in the present analysis. The study results are displayed in table 1.

Table 1.

Study results

\begin{tabular}{|l|c|c|c|}
\hline cN at presentation & cN0 (107) & cN1-2 (115) & Overall (222) \\
\hline ALND performed & 11 & 65 & 76 \\
without SLNB & 11 & 19 & 30 \\
$\quad$ Node-negative & 0 & 46 & 46 \\
\hline Node-positive & 65 & 32 & 97 \\
\hline SLNB (-) & 31 & 18 & 49 \\
\hline SLNB (+) & 8 & 3 & 11 \\
Micrometastasis & 23 & 15 & 38 \\
Macrometastsis & 21 & 11 & 32 \\
ALND(-) & 7 & 1 & 8 \\
ALND(+); $\leq 2$ & & 6 & 9 \\
additional LN(+) & 3 & 6 & \\
ALND (+); >2 & & & \\
additional LN(+) & 3 &
\end{tabular}

The axillary conversion rate in the cN1-2 group was $44.3 \%$ (51/115 patients). Due to the high overestimation rate $(39.5 \%)$ of post-treatment MRI, used for the nodal status re-evaluation, SLNB procedure was performed for only $27.8 \%$ (32/115) patients diagnosed with axillary metastasis.

Although pre-treatment AUS is considered the most reliable method for lymph node evaluation, the underestimation rate calculated for the cN0 group in the present analysis was $29 \%$. However, the risk of underestimation of ypN2-3 status in the same group was only $2.8 \%$. 


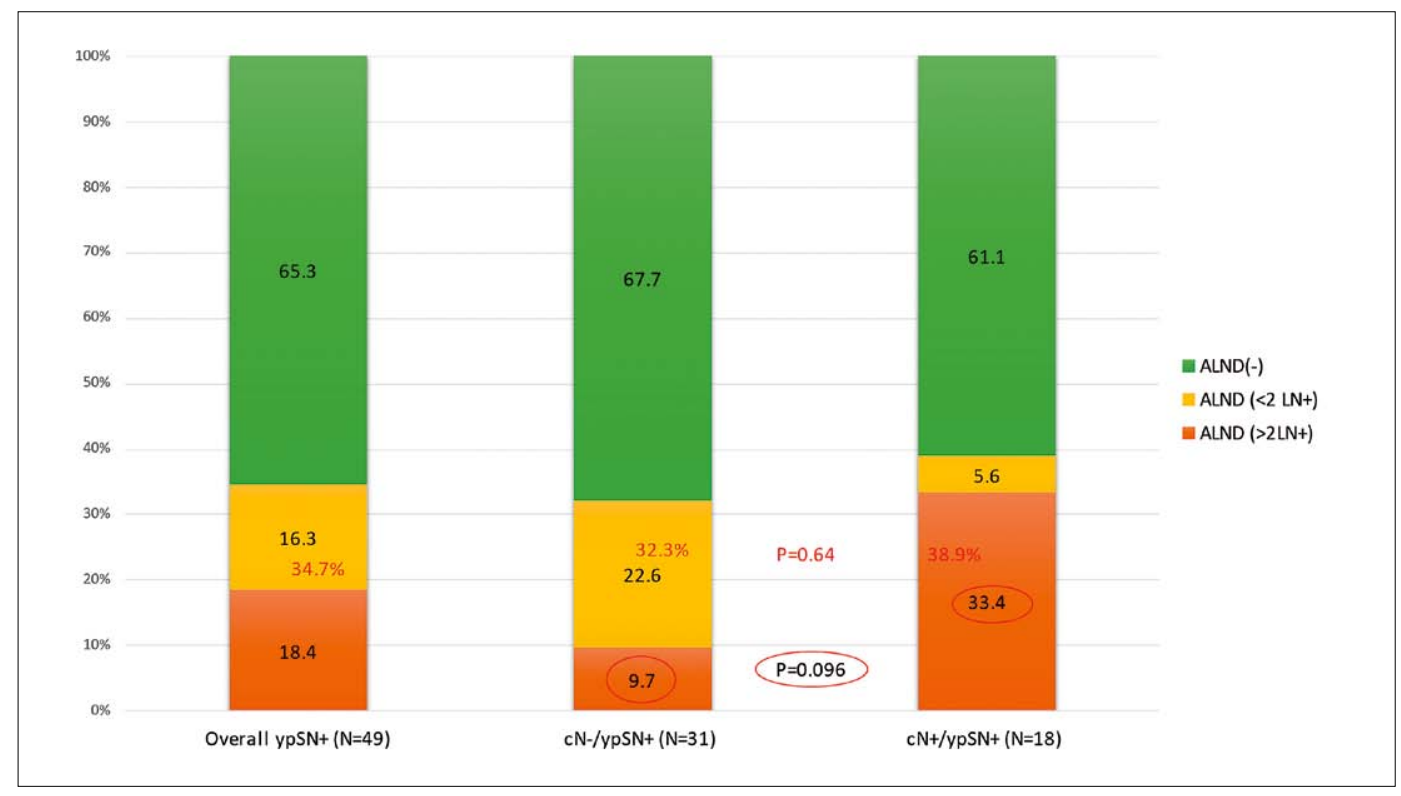

Figure 1 The risk of additional nodal involvement and the massive nodal involvement

SLNB procedure was performed in 146 patients $(65.8 \%$ of all study population), and SLN metastasis was detected in 49 cases. However, additional positive lymph nodes were detected in only 18 ALND specimens and in half of those cases less than 3 additional positive non-SLN were involved i.e., the risk of additional nodal involvement in SLN positive population following NST was $34.7 \%$ and the risk of clinically significant nodal involvement of non-SLNs was $18.4 \%$. In addition, the overall risk of additional nodal involvement was not significantly different between cN0 and cN1-2 subgroups (Pearson Chi-square, $\mathrm{p}=0.64$ ), as well as the risk of massive nodal involvement, although the last one demonstrated a trend toward it (Fisher exact one-tailed test, $\mathrm{p}=0.096)$; both shown in figure 1 .

The overall risk of non-sentinel lymph node involvement in the sentinel node-positive group of patients following NST is $34.7 \%$ and it is not correlated with the nodal status at presentation $(32.3 \%$ vs. $38.9 \%, p=0.64)$. However, there is a trend toward significant lower risk of the massive non-sentinel node involvement (defined as more than 2 non-sentinel lymph nodes involved in addition to sentinel node metastasis) among the patients presented with uninvolved axilla compared to those diagnosed with nodal disease $(9.7 \%$ vs. $33.4 \%, \mathrm{p}=0.096$ )
In almost $1 / 4$ of positive SLN (22.4\%), in both $\mathrm{cN} 0$ and cN1-2 groups, only micro-metastasis were detected, but ALND was performed due to current recommendations. Nevertheless, in neither ALND sample we did not discover additional disease i.e., in the present analysis, a strong correlation exists between the size of SLN metastasis and the risk of additional nodal disease (Fisher exact one-tailed test, $\mathrm{p}=0.027$ ) as well as among the number of SLN involved and the risk of non-sentinel lymph nodes involvement (Fisher exact onetailed test, $\mathrm{p}=0.016$ ), as shown in figures 2 and 3 .

The risk of non-sentinel lymph node involvement in sentinel lymph node-positive patients is significantly higher for patients with the macrometastatic disease compared to those with only micro-metastasis detected in the sentinel lymph node ( $0 \%$ vs. $25.8 \%, p=0.027$ ) and is gradually increasing with the number of sentinel lymph nodes affected.

The risk of non-sentinel lymph node involvement is significantly higher in a group of patients with more than 2 sentinel lymph nodes affected compared to those with up to 2 lymph nodes involved with metastatic disease $(16.2 \%$ vs. $66.7 \%$, $\mathrm{p}=0.016$ )

Of all standard elements of the histopathological report for CNB specimen, as well as for the surgical specimen (ER, PR and HER2 status, Ki67, 


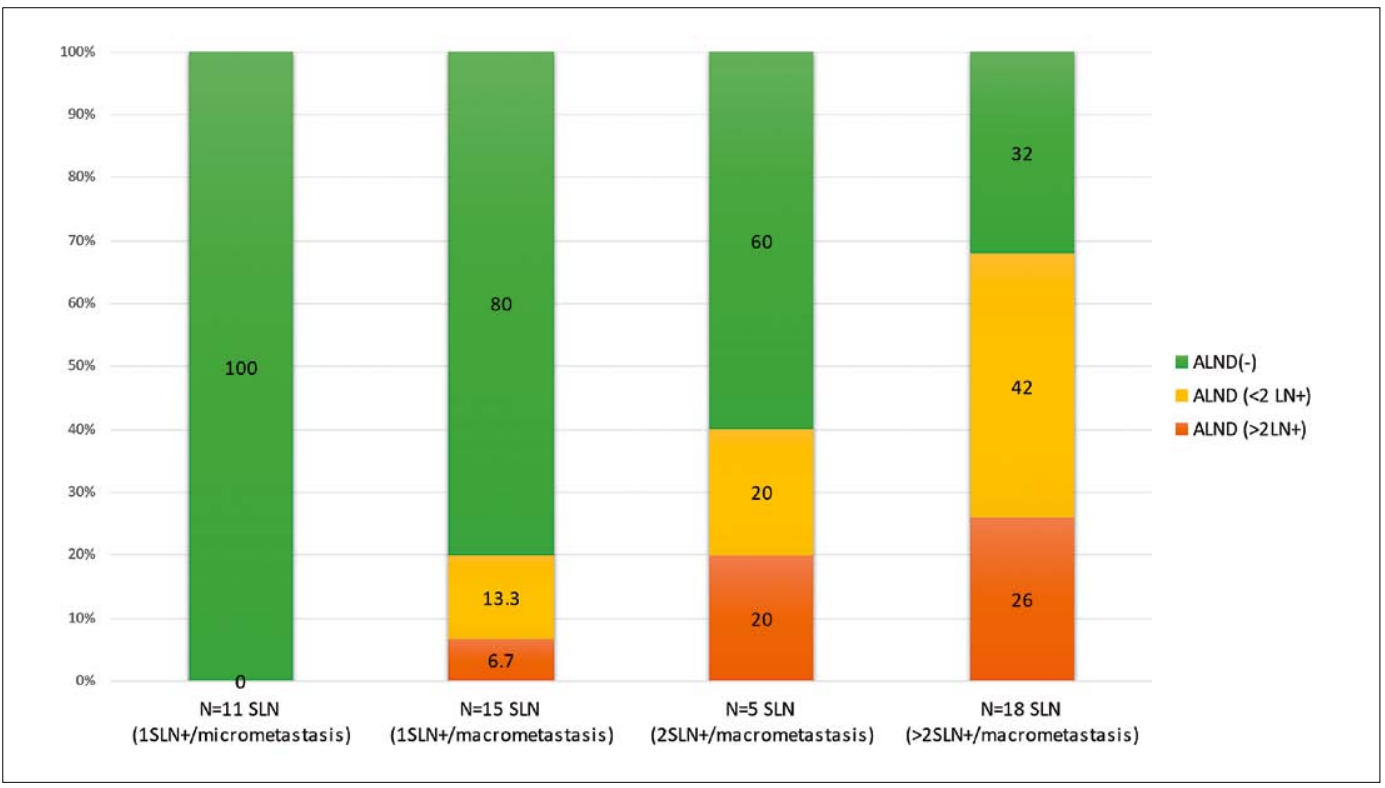

Figure 2 The risk of additional nodal involvement and massive nodal involvement is related to the size of the metastasis and the number of involved sentinel lymph nodes

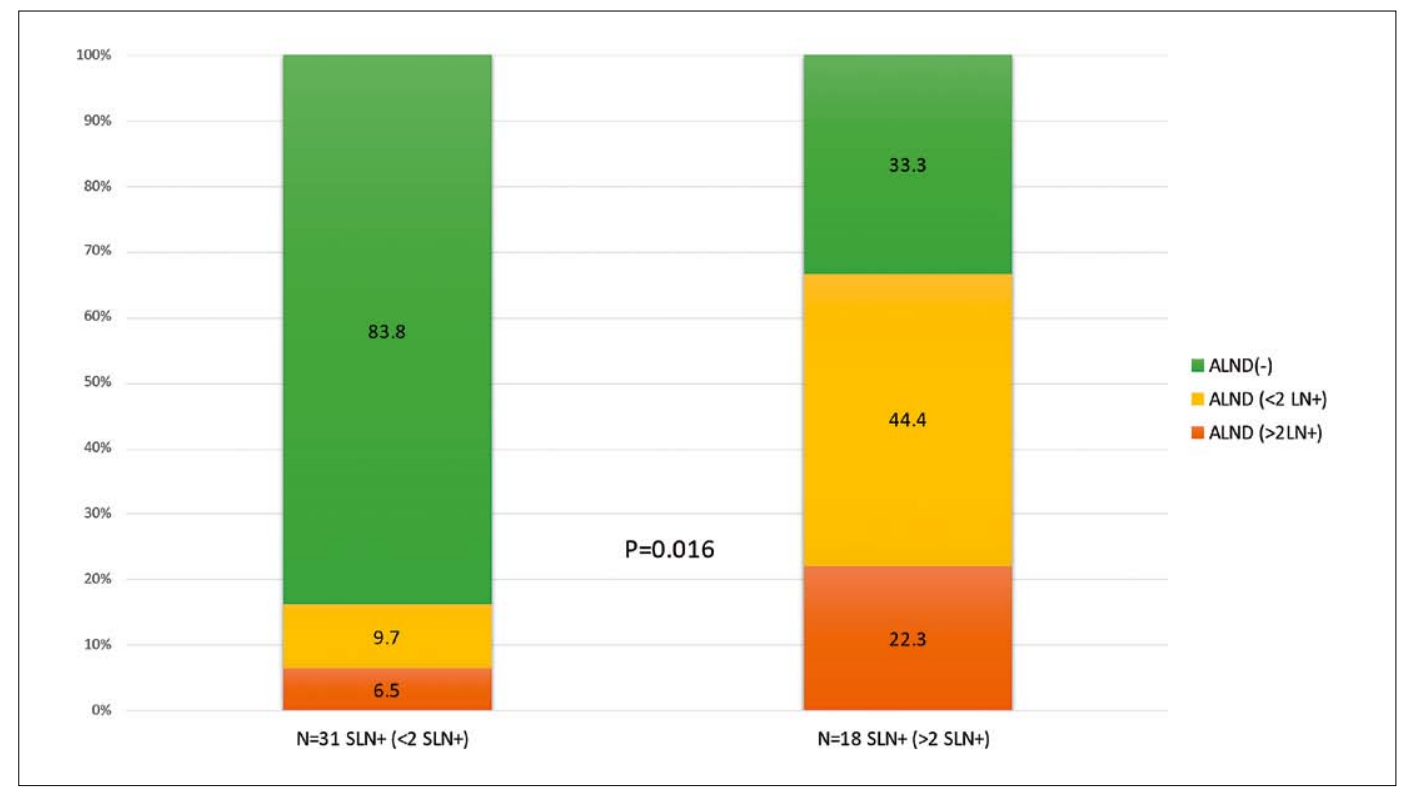

Figure 3 The risk of additional nodal involvement is significantly higher in cases where metastasis is detected in more than 2 SLN.

presence of lymphatic vascular invasion, grade, cellularity, immunophenotype, TILs, and size of the residual disease in the breast), in this analysis only 2 had shown statistically significant correlation with the risk of non-SLN involvement in the
SLN positive cases; percentage of TILs in the surgical breast tissue specimens (Mann-Whitney $\mathrm{U}$ test, $\mathrm{p}=0.012$; negative correlation) and the size of the residual disease in the breast (Mann-Whitney $\mathrm{U}$ test, $\mathrm{p}=0.014$; positive correlation). 


\section{DISCUSSION}

Uninvolved axilla in $56.8 \%$ of the whole postNST population and the conversion rate of $44.5 \%$ in a cN1-2 group are strong arguments for the adoption of SLNB procedure in the neoadjuvant setting of BC treatment, not only for the earlystage BC patients but also for those patients diagnosed with the axillary metastasis.

According to our analysis, as well as the literature data, post-NST MRI of the axilla, with a false positive rate of $39.5 \%$, is not the optimal method to guide the decision-making process for surgical management of the axilla $(19,20)$. Neither imaging method is jet proven to be enough reliable for axillary staging following NST, including PETCT and AUS(21-23). However, reliable pre-treatment AUS, with the underestimation rate of only $2.8 \%$, for $y p N 2-3$ status in the $\mathrm{cN} 0$ population, could be a very helpful tool in the further decisionmaking process for those SLN positive patients following NST diagnosed with cN0 disease.

In all relevant BC treatment guidelines $(11,12)$, ALND is still considered a mandatory procedure in all cases of SLN involvement following NST, irrespective of nodal status at presentation. As in the upfront surgery setting, due to underestimation of AUS, $20-30 \%$ of patients diagnosed as cN0 (29\% in the present analysis), would eventually have metastatic disease detected in SLN. If treated without NST, ALND would be omitted for the majority of those patients, and AxRT would be recommended for those with a higher risk of recurrence. However, following NST, in the same group of patients, ALND is still obligatory for all cases with metastasis detected in SLN, irrespective of its size and the number of SLN involved. The former literature data $(13,24)$ did not show a correlation with the size of SLN metastasis and the risk of non-SLN involvement, and the overall risk in those previous analyses was significantly higher than the average of $30 \%$ documented in the upfront surgery studies(1-6). However, our results did not confirm those findings.

The overall risk of additional nodal involvement for SLN positive patients of $34.7 \%$, calculated in our analysis, is not significantly different from the risk in the Z0011, AMAROS, and OTOASOR trials(1-4). In all mentioned trials, this risk did not translate in any clinical significance after a long-term follow-up period, however, the clinical significance following NST is jet unknown and should merely be determined by several ongoing prospective randomized controlled trials(25-28).

However, while waiting for the results of those trials, we should consider omitting ALND for the SLN-positive patients diagnosed with uninvolved axilla, as the risk for ypN2-3 status in the whole cN0 population is only $2.8 \%$.

Could we offer AxRT instead of ALND for selected subgroups of post-NST SLN-positive patients diagnosed as cN1-2? There was no significant difference in the overall risk of additional nodal involvement among SLN-positive cN0 and cN1-2 patients in the present analysis. However, the risk of massive non-SLN involvement was higher in a cN1-2 group, although did not reach statistical significance, probably due to the small sample size. Nevertheless, the risk of non-sentinel lymph node involvement was found to correlate well with the size of SLN metastasis as well as with the number of involved SLNs in both groups. In addition, a strong correlation between the size of the residual disease and the presence of TILs in the breast tissue specimen is found in this analysis as well as in the literature data(29-32). Although new clinical and pathological biomarkers are needed in this field, those presented in our study could already be implemented in the decisionmaking process.

\section{CONCLUSION}

Due to the implementation of the SLNB procedure in the neoadjuvant setting, as well as with optimal multidisciplinary patient selection, unnecessary ALND is already avoided in $60.7 \%$ of the cN0 group and could be avoided for $44.3 \%$ of the cN1-2 group. However, it may be additionally omitted in both groups, by respecting clinical and pathological biomarkers of low risk for non-SLN involvement in post-NST SLN-positive patients. According to our results, the most powerful biomarkers are the size of the SLN metastasis, the number of involved SLN and nodal status at presentation, presence of TILs in the post-NST surgical breast tissue specimen and the size of the residual disease in the breast.

Considering that the analysis has included all the patients treated in our institution since the SLNB implementation in the neoadjuvant setting, 
we have already included the above mentioned biomarkers of the low risk in our multidisciplinary decision-making process, with the goal of omission of unnecessary ALND.

\section{Acknowledgement: none}

Statement of Ethics: This research was conducted ethically in accordance with the World Medical Association Declaration of Helsinki and was approved by the Ethics Committee of Clinical Hospital Center Rijeka. Written informed consent from participants was not required for this retrospective study in accordance with local/national guidelines.

Conflict of Interest Statement: The authors have no conflict of interest to declare.

Funding Sources: The authors have no funding sources to declare.

Author Contributions: Car Peterko A, Avirović M, Valković Zujić P, Rajković Molek K, Belac Lovasić I. and Lovasić F. contributed to the conception of work, acquisition, analysis, interpretation of data, and revising the work. All authors give the final approval of this version and agree to be accountable for all aspects of the work.

\section{REFERENCES}

1. Giuliano AE, McCall L, Beitsch P, Whitworth PW, Blumencranz $\mathrm{P}$, Leitch AM, et al, Locoregional recurrence after sentinel lymph node dissection with or without axillary dissection in patients with sentinel lymph node metastases: the American College of Surgeons Oncology Group Z0011 randomized trial. Ann Surg. 2010;252:426-432. doi: 10.1097/SLA.0b013e3181f08f32.

2. Giuliano AE, Ballaman KV, Mc Call L, Beitsch PD, Brennan MB, Kelemen PR et al, Effect of axillary dissection vs no axillary dissection on 10-year overall survival among women with invasive breast cancer and sentinel node metastasis The ACOSOG Z0011 (Alliance) randomized clinical trial.JAMA 2017;318(10):918926. doi: 10.1001/jama.2017.11470

3. Donker M, van Tienhoven G, Straver ME, Meijnen P, van de Velde CJ, Mansel RE et al. Radiotherapy or surgery of the axilla after a positive sentinel node in breast cancer (EORTC 10981-22023 AMAROS): a randomised, multicentre, open-label, phase 3 non-inferiority trial. Lancet Oncol. 2014;15(12):1303-10. doi: 10.1016/S1470-2045(14)70460-7

4. Savolt A, Peley G, Polgar C, Rubovszky G, Kovacs E, Gyorffy B et al. Eight-year follow up result of the OTOASOR trial: The optimal treatment of the axilla surgery or radiotherapy after positive sentinel lymph node biopsy in early-stage breast cancer; A random- ized, single centre, phase III, non-inferiority trial. Eur J Surg Oncol. 2017;43(4):672-679. doi: 10.1016/j.ejso. 2016.12.011.

5. Galimberti V, Cole BF, Zurrida S, Viale G, Luini A, Veronesi $\mathrm{P}$, et al. Axillary dissection versus no axillary dissection in patients with sentinel-node micrometastases (IBCSG 23-01): a phase 3 randomised controlled trial. Lancet Oncol. 2013;14:297-305. doi: 10.1016/ S1470-2045(13)70035-4.

6. Galimberti V, Cole BF, Viale G, Veronesi P, Vicini E, Intra $\mathrm{M}$ et al. Axillary dissection vs.no axillary dissection in patients with cT1-T2 cN0 M0 breast cancer and micrometastases only in the sentinel node: ten-year results of the IBCSG 23-01 trial. Lancet Oncol. 2018: 19;1385-93. doi: 10.1016/S1470-2045(18)30380-2.

7. Xing Y, Foy M, Cox DD, Kuerer HM, Hunt KK, Cormier JN. Meta-analysis of sentinel lymph node biopsy after preoperative chemotherapy in patients with breast cancer. Br J Surg. 2006;93(5):539-546. doi: 10.1002/bjs.5209.

8. Kelly AM, Dwamena B, Cronin P, Carlos RC. Breast cancer sentinel node identification and classification after neoadjuvant chemotherapy - systematic review and meta analysis. Acad Radiol. 2009;16(5):551-563. doi: 10.1016/j.acra.2009.01.026

9. Tan VKM, Goh BKP, Fook-Chong S, Khin LW, Wong WK, Yong WS. The feasibility and accuracy of sentinel lymph node biopsy in clinically node-negative patients after neoadjuvant chemotherapy for breast cancer - A systematic review and meta-analysis. J Surg Oncol. 2011;104:97-103. doi: 10.1002/jso.21911.

10. Tee SR, Devane LA, Evoy D, Rothwell J, Geraghty J, Prichard RS et al. Meta-analysis of sentinel lymph node biopsy after neoadjuvant chemotherapy in patients with initial biopsy-proven node-positive breast cancer. Br J Surg. 2018;105(12):1541-1552. doi: 10.1002/ bjs.10986.

11. Curigliano G, Burstein HJ, Winer EP, Gnant M, Dubsky P, Loibl S, et al. De-escalating and escalalating treatment for early-stage breast cancer: The St. Gallen international consensus conference on primary therapy of early breast cancer. Ann Oncol. 2017;28:17001712. doi: 10.1093/annonc/mdx308.

12. NCCN Clinical practice guidelines in oncology. Breast Cancer. Version 3.2020.-March 6. 2020., available at: https://www.nccn.org/professionals/physician_gls/ pdf/breast.pdf. Accessed Mart 30, 2020.

13. Boileau JF, Poirier B, Basik M, Holloway CM, Gaboury L, Sideris L, et al. Sentinel node biopsy after neoadjuvant chemotherapy in biopsy-proven node-positive breast cancer: the SN FNAC study. J Clin Oncol. 2015; 33(3):258-64. doi: 10.1200/JCO.2014.55.7827.

14. Lakhani SR, Ellis IO, Schnitt SJ, Tan PH, van de Vijver MJ. WHO classification of tumors of the breast, Lyon: WHO, 2012.

15. Hortobagyi GN, Connolly JL, D’Orsi CJ, Edge SB, Mittendorf EA, Rugo HS, et al. Breast. In: AJCC cancer 
staging manual, eight edition. Chicago: The Americanc of surgeons ACS, 2018. p.589-628. doi 10.1007/9783-319-40618-3_48.

16. Salgado R, Denkert C, Demaria S, Sirtaine N, Klauschen F, Pruneri G, et al. The evaluation of tumorinfiltrating lymphocytes (TILs) in breast cancer: recommendations by an International TILs Working Group 2014. Ann Oncol. 2015:26(2):259-71. doi: 10.1093 /annonc/mdu450.

17. Allison KH, Hammond HME, Dowsett M, McKernin SE, Carey LA, Fitzgibbons PL, et al. Estrogen and progesterone receptor testing in breast cancer: American society of clinical oncology/College of American pathologists guideline update. Arch Pathol Lab Med. 2020:144(5):545-563. doi: 10.5858/arpa.2019-0904-SA.

18. Wolff AC, Hammond HME, Allison KH, Harvey BE, Mangu PB, Bartlett JMS, et al. Human epidermal growth factor receptor 2 testing in breast cancer American society of clinical oncology/College of American pathologists clinical practice guideline focused update. Arch Pathol Lab Med. 2018;142(11):1364-1382. doi: 10.5858/arpa.2018-0902-SA

19. Webber JJ, Jochelson MS, Eaton E, Zabor EC, Barrio AV, Gemignani MLet al. MRI and prediction of pathologic complete response in the breast and axilla after neoadjuvant chemotherapy for breast cancer. J Am Coll Surg. 2017;225(6):740-746. doi: 10.1016/j.jamcollsurg. 2017.08.027.

20. Liang X, Yu J, Wen B, Xie J, Cai Q, Yang Q. MRI and FDG-PET/CT based assessment of axillary lymph node metastasis in early breast cancer: a meta-analysis. Clin Radiol. 2017;72(4):295-301. doi: 10.1016/j. crad.2016.12.001.

21. Schipper RJ, van Roozendaal LM, de Vries B, Pijnappel RM, Beets-Tan RG, Lobbes MB, Smidt ML. Axillary ultrasound for preoperative nodal staging in breast cancer patients: is it of added value? Breast. 2013; 22(6):1108-13. doi: 10.1016/j.breast.2013.09.002.

22. Zhang $\mathrm{K}$, Zhu Q, Jiawei DS and Chang LC. A new model incorporating axillary ultrasound after neoadjuvant chemotherapy to predict non-sentinel lymph node metastasis in invasive breast cancer. Cancer Management and Research. 2020;12:965-972. doi: 10.2147/CMAR.S239921.

23. Boughey JC, Ballman KV, Hunt KK, McCall LM, Mittendorf EA, Ahrendt GM et al. Axillary ultrasound after neoadjuvant chemotherapy and its impact on sentinel lymph node surgery: results from the American college of surgeons oncology group Z1071 trial (Alliance). J. Clin.Oncol. 2015;33(30):3386-3393. doi: 10.1200/JCO.2014.57.8401.

24. Moo TA, Edelweiss M, Hajiyeva S, Stempel M, Raiss $\mathrm{M}$, Zabor EC et al. Is low-volume disease in the sentinel node after neoadjuvant chemotherapy an indica- tion for axillary dissection? Ann Surg Oncol. 2018; 25(6):1488-1494. doi: 10.1245/s10434-018-6429-2.

25. Krug D, Baumann R, Budach W, Dunst J, Feyer P, Fietkau $\mathrm{R}$ et al. Individualization of post-mastectomy radiotherapy and regional nodal irradiation based on treatment response after neoadjuvant chemotherapy for breast cancer. Strahlenther Onkol. 2018;194:607-618. doi: 10.1007/s00066-018-1270-x.

26. Tinterria C, Canavesea G, Bruzzib P, Dozinb B. NEONOD 2: Rationale and design of a multicenter non-inferiority trial to assess the effect of axillary surgery omission on the outcome of breast cancer patients presenting only micrometastasis in the sentinel lymph node after neoadjuvant chemotherapy. Contemp Clin Trials Commun. 2019;17:100496. doi: 10.1016/j.conctc. 2019.100496.

27. Henke G, Knauer M, Ribi K, Hayoz S, Gérard MA, Ruhstaller T. Tailored axillary surgery with or without axillary lymph node dissection followed by radiotherapy in patients with clinically node-positive breast cancer (TAXIS): study protocol for a multicenter, randomized phase-III trial. BMC 2018;19:667. doi: 10.1186/ s13063-018-3021-9

28. Loaec C, Frenel JS, Renaudeau C, Bordes V, Campion $\mathrm{L}$ and Classe JM. Safely avoiding axillary lymphadenectomy after neoadjuvant chemotherapy for patients with proven axillary lymph node involvement early breast cancer? The French Multicenter Prospective Ongoing GANEA 3 Study. Remedy Publications LLC. 2020;5:27552.

29. Takada K, Kashiwagi S, Goto W, Asano Y, Takahashi K, Fujita $\mathrm{H}$ et al. Possibility of avoiding axillary lymph node dissection by immune microenvironment monitoring in preoperative chemotherapy for breast cancer. J Transl Med. 2018;16(1):318. doi: 10.1186/s12967018-1692-3.

30. Caziuc A, Schlanger D, Amarinei G, Dindelegan GC. Can tumor-infiltrating lymphocytes (TILs) be a predictive factor for lymph nodes status in both early stage and locally advanced breast cancer? J Clin Med. 2019;8(4):545. doi: 10.3390/jcm8040545.

31. Tadros AB, Yang WT, Krishnamurthy S, Rauch GM, Smith BD, Valero $\mathrm{V}$ et al. Identification of patients with documented pathologic complete response in the breast after neoadjuvant chemotherapy for omission of axillary surgery. JAMA Surg. 2017;152(7):665-670. doi: 10.1001/jamasurg.2017.0562.

32. Barron AU, Hoskin TL, Day CN, Hwang ES, Kuerer $\mathrm{HM}$, Boughey JC. Association of low nodal positivity rate among patients with ERBB2-positive or triple-negative breast cancer and breast pathologic complete response to neoadjuvant chemotherapy. JAMA Surg. 2018;153(12):1120-1126. doi:10.1001/jamasurg.2018.2696. 


\section{Sažetak \\ AKSILARNU LIMFADENEKTOMIJU TREBALO BI IZOSTAVITI KOD BOLESNICA
SA KARCINOMOM DOJKE I MINIMALNOM REZIDUALNOM BOLESTI U SENTINEL LIMFNOM ČVORU NAKON NEOADJUVANTNOG SISTEMSKOG LIJEČENJA}

A. Car Peterko, M. Avirović, P. Valković Zujić, K. Rajković Molek, I. Belac Lovasić, F. Lovasić

Uvod: U modernom kirurškom pristupu liječenja kacinoma dojke SLNB je univerzalno prihvaćeni standard. Izostavljanje ALND, u slučajevima sa metastazom pronađenom u do dva sentinel limfna čvora, ne utječe na onkološke ishode kod primarno kirurški liječenih pacijentica, Međutim, svaka metastaza detektirana u sentinel limfnom čvoru nakon provedenog neoadjuvantnog sistemskog liječenja još uvijek se smatra apsolutnom indikacijom za ALND.

Pacijenti i metode: Sve pacijentice operirane zbog karcinoma dojke u Kliničkom Bolničkom Centru (KBC) Rijeka nakon provedene neoadjuvantne kemoterapije, u periodu od 2017. do 2020., uključene su u ovu retrospektivnu analizu.

Rezultati: SLNB je učinjena kod 151 od 222 uzastopne pacijentice, a metastaza u sentinel čvoru pronađena je u 49 slučajeva. Rizik metastatske bolesti u ne-sentinel limfnim čvorovima kod sentinel-pozitivnih pacijentica je $34.7 \%$, međutim isključivo u slučajevima sa makrometastazom u sentinel čvoru. Nadalje, kod skupine pacijenica dijagnosticiranih sa klinički i radiološki negativnom aksilom, rizik od ypN2-3 statusa je samo $2.8 \%$

Zaključak: Nakon neoadjuvantne kemoterapije ALND je overtreatment u 65.3\% sentine-pozitivnih pacijentica. Izostavljanje ALND uz zračenje aksile nakon provedenog neoadjuvantnog liječenja je opcija koju bi trebalo razmotriti za sentinelpozitivne bolesnice sa mikro-metastazom u sentinel čvoru, kao i za bolesnice sa malim volumenom makrometastatske bolesti u sentinel limfnim čvorovima, a koje su inicijalno dijagnosticirane sa klinički negativnom aksilom.

KLJUČNE RIJEČI: rak dojke, neoadjuvantna kemoterapija, biopsija sentinel limfnog čvora 